MaPan : Jurnal Matematika dan Pembelajaran

p-ISSN: 2354-6883 ; e-ISSN: 2581-172X

Volume 4, Nomor 1, Juni 2016

\title{
MENINGKATKAN KEMAMPUAN PEMECAHAN MASALAH MELALUI PEMBELAJARAN KOOPERATIF THINK-TALK-WRITE PADA PESERTA DIDIK KELAS VIII1 MTsN MODEL MAKASSAR
}

\author{
Andi Dian Angriani'1), Bernard2), Rahmawati Nur'3), Nurjawahirah") \\ 1Jurusan Pendidikan Matematika, FTK UIN Alauddin Makassar \\ ${ }^{1}$ Kampus II: Jalan H. M. Yasin Limpo Nomor 36 Samata-Gowa \\ 2Jurusan Matematika, FMIPA Universitas Negeri Makassar \\ 2Kampus: Jalan Mallengkeri Raya, Parang Tambung, Makassar, 90224 \\ 3,4MTsN Model Makassar \\ 3,4Alamat: Jalan A. P. Pettarani No. 1A, Mannuruki, Tamalate, Makassar, 90221 \\ E-mail: dian.angriani@uin-alauddin.ac.id ${ }^{1)}$, nard_unm@yahoo.com ${ }^{2}$,

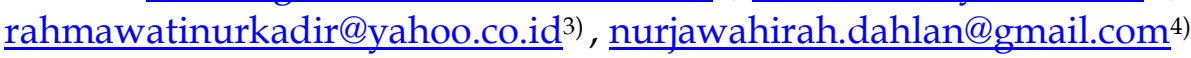

\begin{abstract}
Abstrak
Penelitian ini bertujuan untuk: (1) mendeskripsikan penerapan pembelajaran kooperatif Think-Talk-Write (TTW) yang dapat meningkatkan kemampuan pemecahan masalah matematika pada peserta didik kelas VIII 1 MTsN Model Makassar, (2) mendeskripsikan peningkatan kemampuan pemecahan masalah matematika melalui penerapan pembelajaran kooperatif Think-Talk-Write pada peserta didik kelas VIII 1 MTsN Model Makassar. Penelitian ini dilaksanakan dalam dua siklus, masing-masing siklus terdiri dari 4 tahap, yaitu tahap perencanaan (planning), pelaksanaan tindakan (acting), observasi (observing)/evaluasi (evaluating) dan refleksi (reflecting). Hasil penelitian menunjukkan bahwa: (1) Pembelajaran kooperatif Think-Talk-Write dapat meningkatkan kemampuan pemecahan masalah matematika, meliputi: (a) pada tahap berpikir (think), peserta didik membaca dan mamahami LKPD yang dibagikan secara individu dan diberi kesempatan untuk bertanya jika ada hal yang kurang dipahami. (b) pada tahap berdiskusi (talk), peserta didik terdiri dari 4 orang, berdiskusi secara berpasangan kemudian dipertukarkan dengan pasangan lain dalam kelompoknya, dan diberikan kesempatan untuk bertanya. (c) pada tahap menulis (write), setelah berdiskusi menyatukan pendapat, peserta didik menuliskan hasil diskusinya secara individual, (2) peningkatan kemampuan pemecahan masalah tersebut sebagai berikut: pada siklus I, rata-rata hasil belajar peserta didik 72,85 meningkat menjadi 89,63 pada siklus II. Pada siklus I, terdapat 18 siawa (45\%) yang telah mencapai nilai KKM namun ketuntasan belajar secara klasikal belum tercapai. Sedangkan dari hasil tes siklus II, terdapat 33 peserta didik $(82,5 \%)$ yang telah mencapai nilai KKM dan ketuntasan belajar secara klasikal sudah tercapai.
\end{abstract}

Kata Kunci: Kooperatif TTW, Kemampuan Pemecahan Masalah 
$\mathrm{M}$ atematika adalah ilmu dasar yang memegang peranan penting dan memberikan andil sangat besar dalam kehidupan manusia. Untuk itu, mata pelajaran matematika perlu diberikan kepada semua peserta didik di setiap jenjang pendidikan.

Berdasarkan permendiknas Nomor 22 tahun 2006 tentang Standar Isi (SI) yang tertuang dalam Kurikulum Tingkat Satuan Pendidikan (KTSP) disebutkan bahwa salah satu kemampuan matematika yang diharapkan dikuasai peserta didik sebagai hasil belajar adalah kemampuan memecahkan masalah. Sementara itu, kondisi pembelajaran di kelas VIII MTsN Model Makassar menunjukkan bahwa kemampuan pemecahan masalah peserta didik masih tergolong rendah. Seperti halnya pada hasil ulangan harian matematika yang disajikan pada tabel berikut:

Tabel 1. Hasil Ulangan Harian Matematika yang Berkaitan dengan Pemecahan Masalah Pada Pokok Bahasan Sistem Persamaan Linear Dua Variabel di Kelas VIII MTsN Model Makassar Selama 2 Tahun Terakhir

\begin{tabular}{cccc}
\hline No. & Tahun Pelajaran & Jumlah Peserta didik & Rata-rata \\
\hline 1. & $2012 / 2013$ & 391 & 66,78 \\
2. & $2013 / 2014$ & 402 & 64,83 \\
\hline
\end{tabular}

Sumber : MTsN Model Makassar

Begitupun kemampuan peserta didik di kelas VIII 1 dalam memecahkan masalah matematika, mereka kesulitan menemukan solusi dari masalah yang diberikan. Sebagai contoh, penulis memberikan soal sebagai kepada 40 peserta didik kelas VIII1 “Harga 2 buku dan 4 pulpen adalah Rp13.000,00, sedangkan harga 3 buku dan 1 pulpen adalah Rp12.000,00. Berapakah harga 4 buku dan 3 pulpen?" diantara 40 peserta didik, hanya 17 peserta didik yang mampu menyelesaikan soal tersebut, sedangkan 15 orang peserta didik sama sekali tidak dapat menyelesaikan soal di atas dan selebihnya hanya mengerjakan dengan melihat contoh yang ada di buku tanpa mengerti apa yang mereka kerjakan.

Rendahnya kemampuan peserta didik untuk memecahkan masalah matematika diakibatkan oleh beberapa faktor antara lain: pembelajaran masih cenderung didominasi oleh guru (teacher center). Di samping itu, peserta didik kurang diberi kesempatan untuk berpikir maupun bertaya jika ada soal/ masalah yang diberikan serta peserta didik lebih sering mengerjakan soal 
dalam bahasa dan simbol matematika yang tidak berdasarkan realitas kehidupan sehari-hari.

Bertitik tolak dari permasalahan dan dugaan, maka yang menjadi telaah utama dalam penelitian ini adalah meningkatkan kemampuan pemecahan masalah matematika melalui penerapan pembelajaran kooperatif Think-TalkWrite.

Iru dan Ode (2012:67) menegaskan bahwa pembelajaran kooperatif Think-Talk-Write merupakan pembelajaran kooperatif yang kegiatan pembelajarannya melalui kegiatan berpikir (think), berbicara/berdiskusi, bertukar pendapat (talk) serta menuliskan hasil diskusi (write) agar tujuan pembelajaran dan kompetensi yang diharapkan dapat tercapai".

Berdasarkan latar belakang di atas, maka penulis tertarik untuk melakukan penelitian dengan judul "Meningkatkan kemampuan pemecahan masalah matematika melalui penerapan pembelajaran kooperatif Think-TalkWrite (TTW) pada peserta didik kelas VIII 1 MTsN Model Makassar".

\section{TINDAKAN}

Tindakan yang tepat untuk meningkatkan kemampuan pemecahan masalah matematika adalah penerapan pembelajaran kooperatif Think-TalkWrite.

\section{Pengertian dan Konsep Pembelajaran Think-Talk-Write}

Secara etimologi Think-Talk-Write dalam kamus Echols, J.M. dan Shadily,H. (2005), think diartikan dengan "berfikir", talk diartikan "berbicara", sedangkan write diartikan sebagai "menulis". Jadi Think-Talk-Write bisa diartikan sebagai berfikir, berbicara, dan menulis. Sedangkan pembelajaran Think-Talk-Write adalah sebuah pembelajaran yang dimulai dengan berpikir melalui bahan bacaan dengan menyimak (think), hasil bacaannya dikomunikasikan dengan presentasi, diskusi (talk), dan kemudian membuat laporan hasil presentasi (write).

a. Think (Berpikir)

Aktivitas berfikir (think) dapat dilihat dari proses membaca soal cerita matematika. Dalam tahap ini peserta didik secara individu memikirkan kemungkinan jawaban, membuat catatan apa yang telah dibaca, baik itu berupa apa yang diketahuinya, maupun langkah-langkah penyelesaian dalam bahasanya sendiri. 
b. Talk (Berbicara)

Setelah tahap "think" dilanjutkan dengan tahap "talk" yaitu berkomunikasi dengan menggunakan kata-kata yang mereka pahami. Fase berkomunukasi (talk) pada strategi ini memungkinkan peserta didik untuk terampil berbicara.

c. Write (Menulis)

Fase "write" yaitu menuliskan hasil diskusi/pada lembar kerja yang disediakan. Aktivitas menulis berarti mengkonstruksi ide, karena setelah berdiskusi antar teman dan kemudian mengungkapkannya melalui tulisan.

\section{Langkah-Langkah Pembelajaran Kooperatif Think-Talk-Write}

Langkah-langkah pembelajaran Kooperatif Think-Talk-Write, yaitu:

a. Guru membagi peserta didik dalam kelompok kecil (3 - 5 peserta didik).

b. Guru membagikan lembar kerja yang memuat soal/ masalah.

c. Peserta didik membaca masalah pada lembar kerja dan membuat catatan kecil secara individu tentang apa yang ia ketahui dalam masalah tersebut (think). Setelah itu peserta didik berusaha meyelesaikan masalah tersebut secara individu.

d. Peserta didik berkolaborasi dengan teman kelompok untuk membahas hasil catatan. Dalam kegiatan ini mereka menggunakan kata-kata yang mereka sendiri menyampaikan ide-ide dalam diskusi (talk).

e. Berdasarkan hasil diskusi, peserta didik secara individu merumuskan pengetahuan berupa jawaban atas soal dalam bentuk tulisan (write).

f. Perwakilan kelompok menyajikan hasil diskusi kelompok, sedangkan kelompok lain diminta memberikan tanggapan.

g. Membuat refleksi.

\section{Kelebihan dan Kekurangan Pembelajaran Kooperatif Think-Talk-Write}

Kelebihan pembelajaran Think-Talk-Write ini adalah sebagai berikut:

a. Mengembangkan pemecahan yang bermakna dalam memahami materi ajar

b. Dengan memberikan soal/ masalah dapat mengembangkan keterampilan berpikir kritis dan kreatif peserta didik.

c. Dengan berinteraksi dan berdiskusi dengan kelompok akan melibatkan peserta didik secara aktif dalam belajar.

d. Membiasakan peserta didik berpikir dan berkomunikasi. 
Kekurangan pembelajaran Think-Talk-Write ini sebagai berikut:

a. Ketika peserta didik bekerja dalam kelompok, terkadang yang mendominasi adalah peserta didik yang mempunyai kemampuan lebih.

b. Guru harus menyiapkan semua media agar dalam menerapkan pembelajaran Think-Talk-Write tidak mengalami kesulitan.

\section{DAMPAK TINDAKAN}

\section{Kemampuan Pemecahan Masalah Matematika}

Kemampuan memecahkan masalah merupakan tujuan umum pengajaran matematika. Cara memecahkan masalah dikemukakan oleh beberapa ahli, diantaranya Dewey dan Polya. Dewey (dalam Rothstein dan Pamela 1990) memberikan lima langkah dalam memecahkan masalah: (1) mengenali/menyajikan masalah, (2) mendefinisikan masalah, (3) mengembangkan beberapa hipotesis, (4) menguji beberapa hipotesis, (5) memilih hipotesis yang terbaik.

Sebagaimana Dewey, Polya (1985) pun menguraikan proses yang dapat dilakukan pada setiap langkah pemecahan masalah. Proses tersebut terangkum dalam empat langkah berikut:1) memahami masalah (understanding the problem); 2) merencanakan penyelesaian (devising a plan); 3) melaksanakan rencana (carrying out the plan); 4) memeriksa proses dan hasil (looking back).

Untuk melaksanakan langkah-langkah pemecahan masalah tersebut, maka diterapkan pembelajaran kooperatif Think-Talk-Write. Sebagaimna yang dikemukakan oleh Yamin dan Ansari, (2012:84) menjelaskan bahwa strategi pembelajaran Think-Talk-Write (TTW) dapat menumbuhkembangkan kemampuan pemecahan masalah, sehingga peranan guru sebagai stimulation of learning benar-benar dapat membantu peserta didik dalam mengkonstruksi pengetahuan.

\section{METODE PENELITIAN}

Penelitian ini adalah penelitian tindakan kelas (classroom action research), dengan siklus: perencanaan, tindakan, observasi/evaluasi, dan refleksi. Lokasi pada penelitian ini dilaksanakan di MTsN Model Makassar, Sul-Sel. Subjek penelitian ini adalah semua peserta didik kelas $\mathrm{VIII}_{1}$ MTsN Model Makassar yang terdiri dari 12 laki-laki dan 28 perempuan. 


\section{FAKTOR YANG DISELIDIKI} berikut:

Faktor-faktor yang diselidiki dalam penelitian ini adalah sebagai

a. Faktor input, yaitu faktor yang berkenan dengan observasi awal, yaitu kemampuan pemecahan masalah matematika peserta didik masih rendah/ belum optimal.

b. Faktor proses, yaitu memantau keaktifan peserta didik dalam proses pembelajaran, antara lain peserta didik yang aktif berpikir, berdiskusi, dan menulis jawaban untuk menyelesaikan soal-soal atau masalah matematika dengan mengikuti langkah-langkah pembelajaran kooperatif Think-TalkWrite.

c. Faktor output, yaitu hasil belajar matematika melalui pembelajaran kooperatif Think-Talk-Write yang dapat meningkatkan kemampuan peserta didik memecahkan masalah matematika.

\section{PROSEDUR PENELITIAN}

Penelitian ini dilaksanakan melalui proses pengkajian berdaur yang terdiri atas 4 tahap seperti gambar di bawah ini.

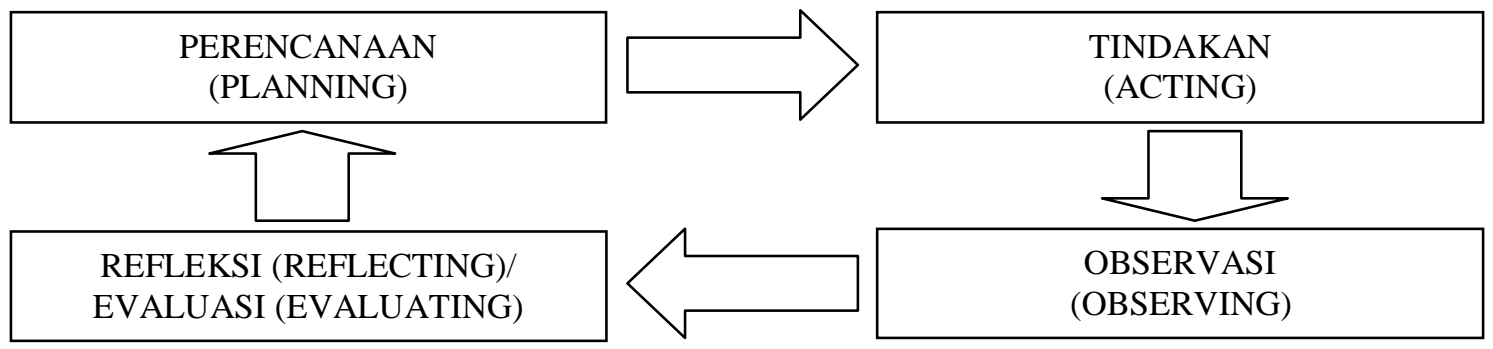

Penelitian ini dilaksanakan dalam dua siklus, dan masing-masing siklus

Gambar 1. Prosedur pelaksanaan PTK (Kemmis, S. dan Mc. Taggart, 1988) pertemuan, aengan maksua untuk mengetanuı кеajegan peıакsanaan proses pembelajaran dan dapat melakukan tahapan perbaikan dengan baik. Masingmasing siklus memiliki 4 tahap, yaitu tahap perencanaan (planning), pelaksanaan tindakan (acting), observasi (observing)/ evaluasi (evaluating) dan refleksi (reflecting).

\section{Siklus I}

Tahap I: Perencanaan

a. Menelaah kurikulum bidang studi Matematika kelas VIII SMP/MTs

b. Mengidentifikasi pembelajaran kooperatif Think-Talk-Write dalam meningkatkan kemampuan pemecahan masalah matematika 
c. Mempelajari, menindaklanjuti, dan mengelaborasi hasil kajian peneliti

d. Bersama dengan anggota tim, guru menyusun RPP yang memuat pembelajaran kooperatif Thnk-Talk-Write, LKPD, lembar observasi untuk merekam kegiatan proses pembelajaran, tes hasil belajar siklus I.

e. Mempersiapkan sarana pembelajaran yang dibutuhkan.

Tahap II: Tindakan

a. Implementasi pembelajaran kooperatif Thnk-Talk-Write di kelas sesuai dengan skenario pembelajaran yang tertuang dalam RPP.

b. Pada akhir siklus I, peserta didik diberikan tes hasil belajar.

Tahap III: Observasi

a. Memantau dan mencatat semua peristiwa (tindakan guru dan respon peserta didik) selama proses pembelajaran berlangsung dengan menggunakan lembar observasi.

b. Melakukan analisis terhadap hasil observasi tindakan.

Tahap II dan III dilaksanakan pada saat bersamaan.

Tahap IV: Refleksi

a. Mendiskusikan hasil yang diperoleh setelah implementasi pembelajaran dalam meningkatkan kemampuan pemecahan masalah matematika

b. Mendiskusikan rencana perbaikan dari siklus I.

\section{Siklus II}

\section{Tahap I: Perencanaan}

a. Menelaah dan menyusun kembali RPP

b. Menelaah dan menyusun kembali lembar kerja peserta didik (LKPD), lembar observasi, tes hasil belajar siklus II

c. Menyiapkan alat evaluasi, untuk mengukur pencapaian hasil belajar peserta didik yang dilaksanakan pada setiap akhir siklus.

Tahap II: Tindakan

a. Melaksanakan proses pembelajaran sesuai RPP yang telah disempurnakan.

b. Pada akhir siklus II, peserta didik diberikan tes hasil belajar.

Tahap III: Observasi

a. Memantau dan mencatat semua peristiwa (tindakan guru dan respon peserta didik) selama proses pembelajaran berlangsung dengan menggunakan lembar observasi

b. Melakukan analisis terhadap hasil observasi tindakan berupa lembar kerja peserta didik serta tes hasil belajar siklus II.

Tahap II dan III dilaksanakan pada saat bersamaan. 
Tahap IV: Refleksi

a. Melakukan finalisasi pembelajaran kooperatif Think-Talk-Write dalam meningkatkan kemampuan pemecahan masalah matematika.

b. Hasil observasi dianalisis untuk dijadikan bahan pemikiran dalam merefleksi kegiatan selama tindakan dilakukan.

\section{LANGKAH-LANGKAH TINDAKAN}

Tindakan yang dilakukan dalam penelitian adalah sebagai berikut:

a. Guru mengorganisasikan peserta didik ke dalam beberapa kelompok kecil, setiap kelompok terdiri dari 3-4 orang yang heterogen.

b. Guru memberikan penjelasan 1-2 contoh masalah kemudian menentukan apa yang diketahui, apa yang ditanyakan, serta menemukan model matematikanya.

c. Guru membagikan Lembar Kerja Peserta Didik (LKPD) kepada masingmasing peserta didik setiap kelompok. Peserta didik secara individu diminta untuk menuangkan gagasan/ide mengenai apa yang diketahui, ditanyakan, dan model matematika dalam bentuk catatan sebelum berdiskusi dengan teman kelompoknya (Think).

d. Setiap kelompok berdiskusi mengenai hasil catatannya yang berisi langkah mengerjakan LKPD yaitu dengan saling menukar ide/gagasan agar diperoleh kesepakatan-kesepakatan dalam kelompok (Talk)

e. Peserta didik diminta untuk menuliskan hasil diskusinya mengenai apa yang diketahui, ditanyakan, dan model matematika berdasarkan masalah yang ada dalam LKPD (Write).

f. Beberapa kelompok mewakili satu kelas mempresentasikan LKPDnya, sedangkan kelompok yang lain diminta untuk memberikan tanggapan.

\section{INDIKATOR KEBERHASILAN}

Indikator keberhasilan setiap akhir siklus ditetapkan berdasarkan ketentuan sebagai berikut:

a. Apabila skor rata-rata hasil belajar peserta didik meningkat melalui penerapan pembelajaran kooperatif Think-Talk-Write.

b. Apabila peserta didik telah mencapai Kriteria Ketuntasan Minimal $(K K M) \geq 75$ dengan Ketuntasan Klasikal $\geq 80 \%$. 


\section{TEKNIK ANALISIS DATA}

\section{Analisis Kuantitatif}

Analisis kuantitatif dilakukan terhadap hasil tes belajar peserta didik dengan menggunakan statistika deskriptif dengan tujuan untuk mengetahui peningkatan kemampuan pemecahan masalah matematika peserta didik setiap pelaksanaan tindakan pada siklus I dan II.

\section{Analisis Kualitatif}

Analisis kualitatif dilakukan terhadap hasil pengamatan terhadap tindakan guru dan respon peserta didik selama pelaksanaan pembelajaran kooperatif Think-Talk-Write setiap pelaksanaan tindakan Siklus I dan II.

\section{HASIL PENELITIAN DAN PEMBAHASAN}

\section{Hasil Penelitian}

\section{Siklus I}

Kegiatan pembelajaran pada siklus I berlangsung dalam tiga kali tindakan. Setiap tindakan dilakukan dalam dua kali pertemuan. Jadi, jumlah pertemuan yang dilakukan selama siklus I adalah enam kali pertemuan.

a. Deskripsi Tindakan

Data kualitatif berupa deskripsi kegiatan peserta didik dan guru selama tiga kali tindakan yang diperoleh dari catatan observasi dan diperkuat dengan dokumentasi. Adapun langkah-langkah yang dilakukan pada siklus I, yaitu:

Pertama, guru membuka pembelajaran dengan apersepsi dan membangkitkan motivasi belajar peserta didik dengan memberikan pertanyaan yang menantang terkait materi yang diajarkan. Guru menyampaikan tujuan pembelajaran serta metode pembelajaran yang akan diterapkan.

Kedua, guru mengorganisasikan 40 orang peserta didik ke dalam beberapa kelompok kecil, setiap kelompok terdiri dari 3 orang peserta didik yang heterogen. Setelah itu, guru menjelaskan 2 contoh soal/masalah.

Ketiga, guru mengarahkan peserta didik berdiskusi dengan teman kelompoknya berdasarkan contoh masalah yang diberikan.

Keempat, guru membagikan lembar kerja peserta didik LKPD secara individu kemudian mengidentifikasi apa yang diketahui dan apa yang ditanyakan, sampai menemukan model matematikanya. Namun masih ada beberapa peserta didik dalam kelompok yang tidak serius dalam membaca LKPD. 
Kelima, setiap peserta didik diarahkan untuk menuangkan gagasan/ide mengenai apa yang diketahui, ditanyakan, dan model matematika dalam bentuk catatan kecil, kemudian setiap kelompok berdiskusi dengan saling menukar ide/gagasan agar diperoleh kesepakatan-kesepakatan dalam kelompok. Pada saat diskusi kelompok berlangsung, masih terlihat 2-3 orang peserta didik yang mondar mandir di dalam kelas (tahap talk belum begitu optimal).

Keenam, peserta didik diarahkan untuk menuliskan hasil diskusinya berdasarkan masalah yang ada dalam LKPD secara berkelompok. Namun, masih ada peserta didik yang masih kebingungan dalam menentukan model matematika dari suatu masalah. Guru pun memberikan masukan dan mengoreksi jika terjadi kesalahan

Ketujuh, guru meminta perwakilan kelompok secara acak untuk tampil mempresentasikan hasil kerja kelompoknya di depan kelas.

b. Deskripsi Hasil

Hasil analisis deskriptif secara kuantitatif tentang tes kemampuan memecahkan masalah matematika setelah diberikan tindakan pada siklus I dapat dilihat pada tabel 2 berikut.

Tabel 2. Statistik Skor Kemampuan Pemecahan Masalah Matematika Pada

Tes Siklus I Melalui Penerapan Pembelajaran Kooperatif Think-TalkWrite kelas VIII $_{1}$ MTsN Model Makassar

\begin{tabular}{cc}
\hline Variabel & Nilai Statistik \\
\hline Subjek penelitian & 40 \\
Skor ideal & 100 \\
Rata-rata & 72,85 \\
Standar deviasi & 8,097 \\
Skor maksimum & 92 \\
Skor minimum & 53 \\
Rentang skor & 39 \\
\hline
\end{tabular}

Tabel 2 menujukkan bahwa skor rata-rata hasil belajar matematika setelah diberikan tindakan adalah 72,85 dari skor ideal 100. Skor tertinggi adalah 92 dan skor terendah adalah 53 dengan standar deviasi 8,097 dan dengan rentang skor 39 yang berarti hasil belajar yang matematika yang 
dicapai peserta didik kelas VIII $_{1}$ MTsN Model Makassar pada tes siklus I tersebar dari skor terendah 53 sampai 92 atau berkisar antara 53\% sampai dengan $92 \%$. Jika dilihat berdasarkan ketercapaian indikator keberhasilan, akan diperlihatkan pada tabel 3 berikut:

Tabel 3. Ketercapaian Indikator Keberhasilan Pada Tes Siklus I (Acuan $\geq 75$ ) di Kelas VIII 1 MTsN Model Makassar

\begin{tabular}{cccc}
\hline \multirow{2}{*}{ Nilai KKM } & \multirow{2}{*}{ Kategori } & \multicolumn{2}{c}{ Siklus I } \\
\cline { 3 - 4 } & & Frekuensi & Presentase \\
\hline$<75$ & jelum Mencapai & 22 & $55 \%$ \\
$\geq 75$ & Mencapai & 18 & $45 \%$ \\
& JUMLAH & 40 & $100 \%$ \\
\hline
\end{tabular}

Berdasarkan tabel 3, jumlah peserta didik yang memperoleh KKM $\geq 75$ adalah 22 orang dan yang memperoleh KKM $<75$ adalah 18 orang. Dengan kata lain, hanya 18 peserta didik (45\%) yang telah mencapai nilai KKM dan ketuntasan belajar secara klasikal belum tercapai. Berikut ketercapaian indikator keberhasilan pada tes siklus I digambarkan dalam grafik 1 berikut.

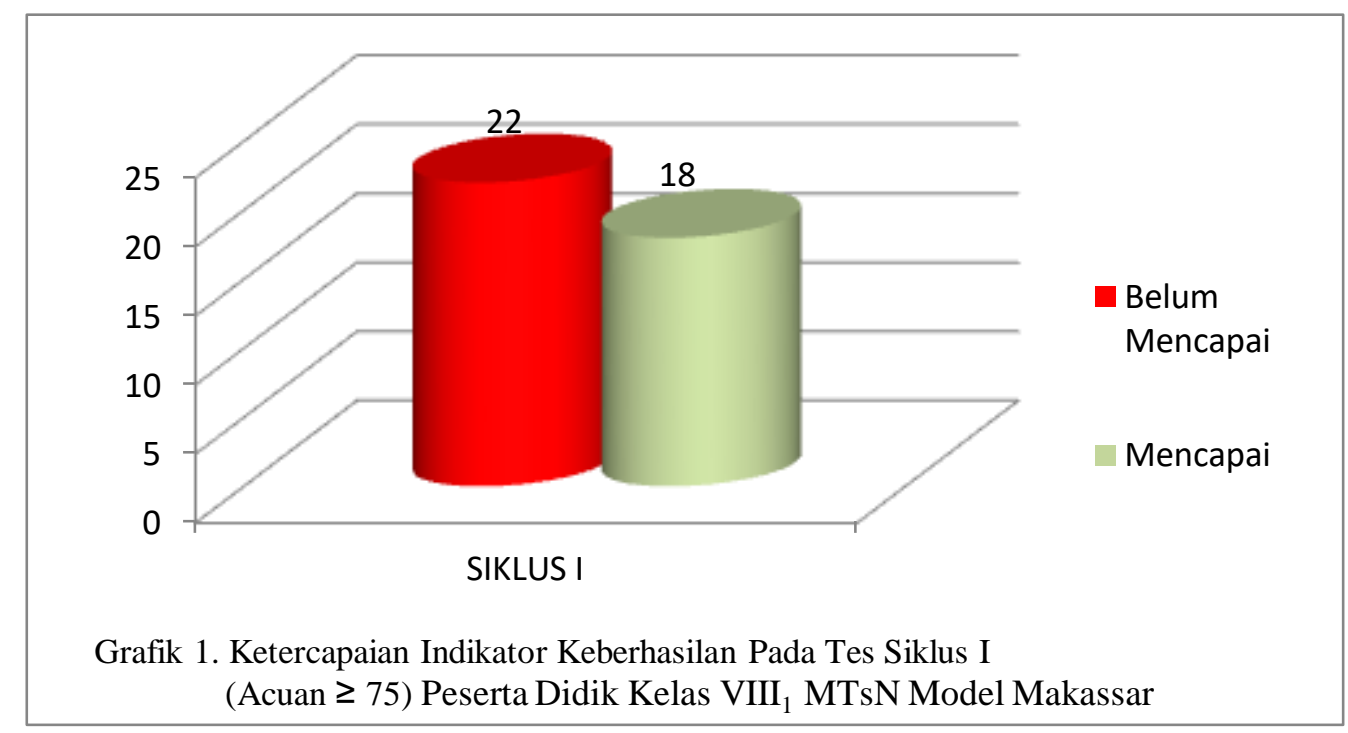

c. Refleksi Siklus I

Berdasarkan pelaksanaan tindakan pada siklus I, rata-rata kemampuan peserta didik memecahkan masalah matematika berdasarkan langkah-langkah 
Think-Talk-Write adalah 72,85. Terdapat 18 peserta didik (45\%) yang telah mencapai nilai KKM namun ketuntasan belajar secara klasikal belum tercapai.

Selain itu, berdasarkan hasil observasi selama pelaksanaan siklus I ada beberapa kendala/ kekurangan yang tampak antara lain sebagai berikut:

1. Pada tahap think, peserta didik diarahkan untuk membaca LKPD secara individu, namun masih ada peserta didik dalam kelompok yang tidak serius dalam membaca LKPD. Hal ini ditandai dengan adanya peserta didik sering mengganggu temannya sebab ada hal yang ternyata mereka kurang pahami pada bacaan tersebut. Oleh karena itu, sebaiknya peserta didik diberikan kesempatan kepada peserta didik untuk bertanya.

2. Pada saat diskusi kelompok berlangsung, masih terlihat 2-3 orang peserta didik yang mondar mandir di dalam kelas (tahap talk belum begitu optimal).

3. Peserta didik masih kebingungan dalam menentukan model matematika dari suatu masalah. Sebaiknya guru memberikan kesempatan untuk bertanya dan memberikan bimbingan kepada kelompok yang membutuhkan.

4. Pada saat guru mengarahkan peserta didik menuliskan hasil diskusinya secara berkelompok (tahap write), dalam satu kelompok hanya satu peserta didik yang menulis, peserta didik yang lain hanya ikut memberikan masukan. Agar kemampuan menulis setiap peserta didik nampak, sebaiknya setiap peserta didik menuliskan jawaban sebagai hasil diskusi dalam kelompoknya.

Kekurangan pada siklus I dapat dijadikan acuan untuk memperbaiki pelaksanaan tindakan pada siklus II dan keberhasilan pada siklus I dapat dipertahankan dan dikembangkan untuk mencapai keberhasilan sesuai dengan modifikasi/ langkah penyempurnaan tindakan yang telah ditetapkan pada siklus II.

\section{Siklus II}

Kegiatan pembelajaran pada siklus II juga berlangsung dalam tiga kali tindakan. Setiap tindakan dilakukan dalam dua kali pertemuan. Jadi, jumlah pertemuan yang dilakukan selama siklus II adalah enam kali pertemuan.

a. Deskripsi Tindakan

Data kualitatif berupa deskripsi kegiatan peserta didik dan guru selama tiga kali tindakan yang diperoleh dari hasil catatan observasi dan diperkuat 
dengan dokumentasi. Adapun langkah-langkah yang dilakukan pada Siklus II, yaitu:

Guru membuka pembelajaran dengan apersepsi dan membangkitkan motivasi belajar peserta didik. Guru mengorganisasikan 40 orang peserta didik ke dalam beberapa kelompok kecil, setiap kelompok terdiri dari 4 orang peserta didik yang heterogen, tujuannya adalah agar setiap kelompok dapat berdiskusi secara berpasangan dan saling bertukar pendapat sebelum berdiskusi dengan teman dalam kelompoknya.

Sebelum guru membagikan LKPD kepada peserta didik, guru memberikan contoh masalah dalam kehidupan sehari-hari yang ada kaitannya dengan pertanyaan yang ada pada LKPD yang akan dibagikan.

Selanjutnya guru membagikan LKPD kepada peserta didik secara individu kemudian mengidentifikasi apa yang diketahui dan apa yang ditanyakan sampai menemukan model matematika dari masalah tersebut. Selanjutnya setiap peserta didik menuangkan gagasan/ide dalam bentuk catatan kecil, kemudian setiap pasangan berdiskusi mengenai hasil catatannya. Setelah memperoleh kesepakatan, peserta didik diarahkan untuk saling menukar ide/gagasan dengan pasangan lain dalam kelompoknya agar diperoleh kesepakatan dalam kelompok.

Guru mengarahkan peserta didik menulis hasil diskusi berdasarkan masalah yang ada dalam LKPD secara individu, setelah itu diarahkan untuk saling bertukar jawaban dengan teman kelompoknya masing-masing sebelum dipresentasikan agar tidak ada lagi kesalahan jawaban dalam kelompok.

Guru meminta dua kelompok maju untuk mempresentasikan hasil diskusi kelompoknya. Kelompok yang lain diminta memberi tanggapan.

b. Deskripsi Hasil

Hasil analisis deskriptif secara kuantitatif tentang tes kemampuan memecahkan masalah matematika setelah diberikan tindakan pada siklus II dapat dilihat pada tabel 4 berikut.

Tabel 4. Statistik Skor Kemampuan Pemecahan Masalah Matematika Pada Tes Siklus II Melalui Penerapan Pembelajaran Kooperatif Think-Talk-Write Kelas VIII 1 MTsN Model Makassar

\begin{tabular}{cc}
\hline Variabel & Nilai Statistik \\
\hline Subjek penelitian & 40 \\
Skor ideal & 100 \\
\hline
\end{tabular}




\begin{tabular}{cc}
\hline Rata-rata & 89,63 \\
Standar deviasi & 8,693 \\
Skor maksimum & 98 \\
Skor minimum & 71 \\
Rentang skor & 27 \\
\hline
\end{tabular}

Tabel 4 menujukkan bahwa skor rata-rata hasil belajar matematika setelah diberikan tindakan adalah 89,63 dari skor ideal 100. Skor tertinggi adalah 98 dan skor terendah adalah 71 dengan standar deviasi 8,693 dan dengan rentang skor 27 yang berarti hasil belajar yang matematika yang dicapai peserta didik kelas VIII 1 MTsN Model Makassar pada tes siklus II tersebar dari skor terendah 71 sampai 98 atau berkisar antara $71 \%$ sampai dengan $98 \%$. Jika dilihat berdasarkan ketercapaian indikator keberhasilan, akan diperlihatkan pada tabel 5 berikut:

Tabel 5. Ketercapaian Indikator Keberhasilan pada Tes Siklus II (Acuan 75) Peserta didik Kelas VIII ${ }_{1}$ MTsN Model Makassar

\begin{tabular}{cccc}
\hline \multirow{2}{*}{ Nilai KKM } & \multirow{2}{*}{ Kategori } & \multicolumn{2}{c}{ Siklus II } \\
\cline { 3 - 4 } & & Frekuensi & Persentase \\
\hline$<75$ & Belum Mencapai & 7 & $17,5 \%$ \\
$\geq 75$ & Mencapai & 33 & $82,5 \%$ \\
& JUMLAH & 40 & $100 \%$ \\
\hline
\end{tabular}

Berdasarkan tabel 5, jumlah peserta didik yang memperoleh KKM $\geq 75$ adalah 33 orang dan yang memperoleh KKM $<75$ adalah 7 orang. Dengan kata lain, terdapat 33 peserta didik $(82,5 \%)$ yang telah mencapai nilai KKM dan ketuntasan belajar secara klasikal sudah tercapai. Berikut ketercapaian indikator keberhasilan pada tes siklus I digambarkan dalam grafik 2 berikut. 


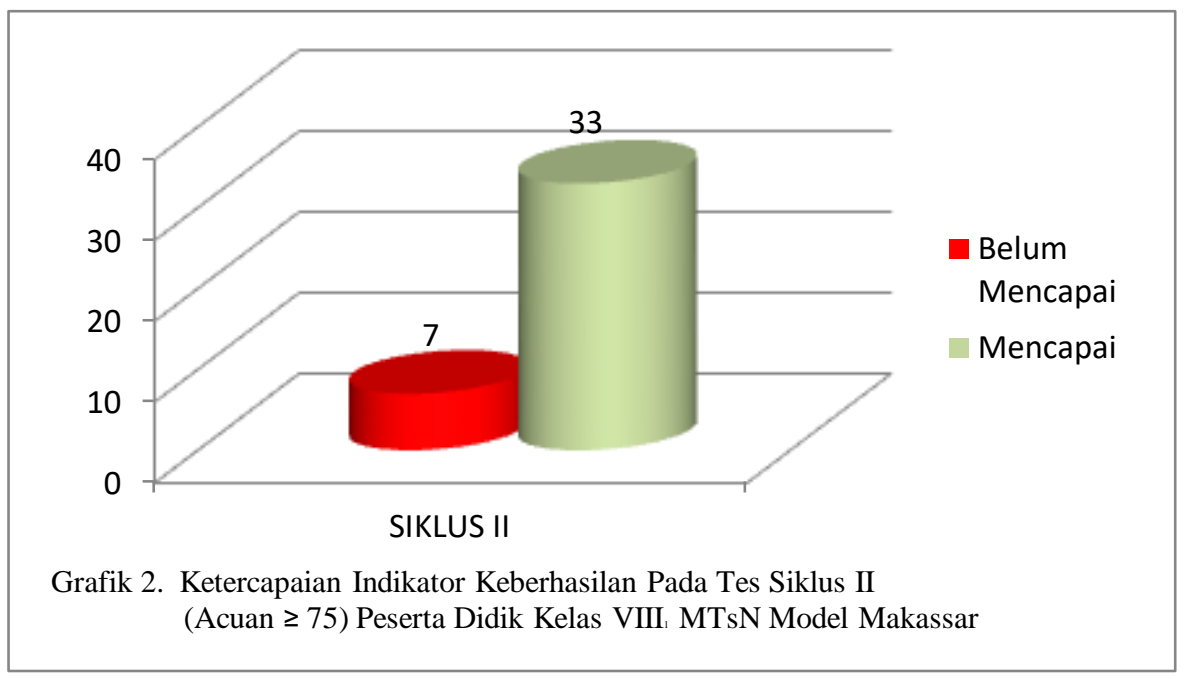

\section{c. Hasil Refleksi Siklus II}

Berdasarkan hasil analisis terhadap tindakan siklus II menunjukkan bahwa kegiatan pembelajaran kooperatif Think-Talk-Write yang telah disempurnakan telah membawa perubahan keaktifan dan dapat meningkatkan kemampuan pemecahan masalah.

Dari segi proses/ tindakan, peserta didik mampu membangkitkan semangat maupun kreativitasnya dalam pembelajaran. Peserta didik tampak aktif mengidentifikasi hal yang diketahui dan ditanyakan serta menemukan model matematika sampai menemukan solusi dari soal/ masalah yang diberikan. Dari segi hasil, rata-rata kemampuan peserta didik memecahkan masalah matematika berdasarkan langkah-langkah Think-Talk-Write adalah 89,63 . Terdapat 33 peserta didik (82,5\%) yang telah mencapai nilai KKM. Oleh karena itu, jumlah peserta didik yang mencapai nilai KKM yang ditentukan dari tindakan siklus II telah mencapai indikator keberhasilan yang ditetapkan, yaitu yaitu $80 \%$ atau lebih dari jumlah seluruh peserta didik (40 orang) mencapai nilai $\mathrm{KKM} \geq 75$. Dalam hal ini, diputuskan untuk mengakhiri penelitian pada siklus II ini.

\section{Pembahasan}

Hasil belajar peserta didik setelah diberikan tindakan pada siklus I dan siklus II dengan menerapkan pembelajaran kooperatif Think-Talk-Write untuk meningkatkan kemampuan pemecahan masalah matematika mengalami peningkatan yaitu pada siklus I rata-rata hasil belajar peserta didik 72,85 meningkat menjadi 89,63 pada siklus II. Dari hasil tes siklus I, terdapat 21 peserta didik (52,5\%) yang telah mencapai nilai KKM namun ketuntasan 
belajar secara klasikal belum tercapai. Sedangkan dari hasil tes siklus II, terdapat 33 peserta didik $(82,5 \%)$ yang telah mencapai nilai KKM dan ketuntasan belajar secara klasikal sudah tercapai.

Ketidaktercapaian indikator keberhasilan pada siklus I disebabkan oleh beberapa faktor, antara lain pada saat guru memberikan contoh soal/ masalah peserta didik belum dilibatkan untuk memikirkan jalan keluar/ solusi dari masalah tersebut, peserta didik kurang terlibat dalam diskusi kelompok ditandai dengan masih terlihat 2-3 orang peserta didik yang mondar mandir di dalam kelas, sehingga talk belum begitu nampak. Di samping itu, peserta didik masih kebingungan dalam menentukan model matematika dari suatu masalah. Sebaiknya guru memberikan kesempatan untuk bertanya dan memberikan bimbingan kepada kelompok yang membutuhkan. Pada saat guru mengarahkan peserta didik menuliskan hasil diskusinya secara berkelompok, dalam satu kelompok hanya satu peserta didik yang menulis, sementara anggota yang lain tidak begitu memperhatikan apa yang ditulis oleh temannya.

Oleh karena itu, pada siklus II dilakukan penyempurnaan tindakan sebagai evaluasi dan refleksi terhadap tindakan yang dilakukan pada siklus I. Ketercapaian indikator keberhasilan pada siklus II disebabkan penerapan pembelajaran kooperatif Think-Talk-Write yang telah diterapkan meliputi langkah-langkah pembelajaran yang sudah tepat sasaran diuraikan sebagai berikut:

a. Pada tahap berpikir (think), peserta didik membaca dan mamahami LKPD yang dibagikan secara individu dan peserta didik diberi kesempatan untuk bertanya jika ada hal yang kurang dipahami.

b. Pada tahap berdiskusi (talk), peserta didik sebelumnya dibagi ke dalam beberapa kelompok kecil yang heterogen, dimana setiap kelompok terdiri dari 4 orang. Peserta didik berdiskusi secara berpasangan. Hasil diskusi secara berpasangan dipertukarkan dengan pasangan lain dalam kelompoknya, sehingga tahap talk dilakukan secara maksimal.

c. Pada tahap menulis (write), peserta didik menuliskan hasil diskusinya secara individual.

Akhirnya, berdasarkan data hasil belajar setiap akhir siklus, pengamatan tindakan guru dan respon peserta didik dapat disimpulkan bahwa penerapan pembelajaran kooperatif Think-Talk-Write dapat meningkatkan kemampuan pemecahan masalah matematika pada peserta didik kelas VIII 1 MTsN Model Makassar. 


\section{SIMPULAN}

Berdasarkan paparan data dan temuan penelitian, hasil penelitian ini dapat disimpulkan sebagai berikut:

a. Pembelajaran kooperatif Think-Talk-Write dapat meningkatkan kemampuan pemecahan masalah matematika, meliputi:

1. Pada tahap berpikir (think), peserta didik membaca dan mamahami secara mendalam LKPD yang dibagikan secara individu dan peserta didik diberi kesempatan untuk bertanya jika ada hal yang kurang dipahami pada bacaan tersebut.

2. Pada tahap berdiskusi (talk), peserta didik sebelumnya dibagi ke dalam beberapa kelompok kecil yang heterogen, dimana setiap kelompok terdiri dari 4 orang. Peserta didik berdiskusi secara berpasangan. Hasil diskusi secara berpasangan dipertukarkan dengan pasangan lain dalam kelompoknya, sehingga tahap talk dilakukan secara maksimal dan peserta didik diberikan kesempatan untuk bertanya jika ada hal yang kurang dipahami.

3. Pada tahap menulis (write), setelah anggota dalam kelompok berdiskusi menyatukan pendapat, peserta didik menuliskan hasil diskusinya secara individual.

b. Peningkatan kemampuan pemecahan masalah tersebut sebagai berikut: pada siklus I, rata-rata hasil belajar peserta didik 72,85 meningkat menjadi 89,63 pada siklus II. Pada siklus I, terdapat 18 siawa (45\%) yang telah mencapai nilai KKM namun ketuntasan belajar secara klasikal belum tercapai. Sedangkan dari hasil tes siklus II, terdapat 33 peserta didik $(82,5 \%)$ yang telah mencapai nilai KKM dan ketuntasan belajar secara klasikal sudah tercapai.

\section{DAFTAR PUSTAKA}

Depdiknas. (2006). Peraturan menteri pendidikan nasioanal republik indonesia tentang standar isi dan standar kompetensi lulusan untuk satuan pendidikan dasar dan menengah (Permen No. 22, tahun 2006). Jakarta: Depdiknas.

Echols, J. M., \& Shadily, H. (2005). Kamus Inggris-Indonesia. Jakarta: PT Gramedia Pustaka Utama.

Iru, L., \& Ode, L. (2012). Analisis penerapan pendekatan, metode, strategi, dan model-model pembelajaran. Bantul, DIY: Multi Press Indo. 
Kemmis, S., \& McTaggart, R. (1988). Action research - some ideas from the action research planner, third edition, ed. Deakin University.

Polya, G. (1985). How to solve it. a new aspect of mathematical method (2nd ed). Princeton, New Jersey : Princeton University Press.

Rothstein, \& Pamela, R. (1990). Educational pyschology. Singapore: Mc GrawHill, Inc.

Yamin, M., \& Ansari, B. I. (2012). Taktik mengembangkan kemampuan individual peserta didik. Jakarta: Gaung Persada Press. 